\title{
CSIRO: fifty years of research
}

CSIRO, the Commonwealth Scientific and Industrial Research Organisation of Australia, celebrates its fiftieth birthday this year. We present in this special supplement a cross-section of the activities of an organisation employing over 2,000 professional scientists. Sir Robert Price, Chairman since 1970, introduces the review.

\section{Looking to the future}

\author{
J. R. Price \\ CSIRO, PO Box 225, Dickson, ACT 2602, Australia
}

\begin{abstract}
Although research in CSIRO will be determined by the significant advances in science as a whole, much emphasis will still be on the use of resources, the environment and consumer-oriented research. This is discussed against a background of increasing interaction between science and politics.
\end{abstract}

Although any attempt to assess the future role of an organisation such as CSIRO can only be highly speculative, it is valuable to try to do so even if nothing more is achieved than the identification of existing deficiencies. But whatever the outcome, it is necessary to devote a little time to considering some of the events that have contributed to the present situation in Australia with regard to science and technology and to the role of CSIRO.

A suitable starting point is the establishment, in 1926, of the Council for Scientific and Industrial Research (CSIR). Among its terms of reference was a major requirement that it initiate and carry out "scientific researches in connection with, or for the promotion of, primary or secondary industries". The Council was given considerable freedom to achieve its aims, and one of its first decisions-a crucial one-was that it should carry out its own research, with its own staff, in its own laboratories. To do this, it set up a number of research divisions and to this day the division remains the basic organisational unit of research in CSIRO.

Initially the emphasis of the Council's work was almost entirely on primary industry, and a succession of useful discoveries helped the new organisation gain acceptance by that industry and by the community in general. This encouraged the Government, in 1936, to provide resources to extend the activities of CSIR into areas of research for secondary industry. This proved to be a wise decision because of the part played by the newly established divisions in the wartime development of the Australian manufacturing industry.

Sir Frederick White deals in the next article with some aspects of those early years and has outlined the background to the transformation in 1949 of the Council (CSIR) into the Commonwealth Scientific and Industrial Research Organisation (CSIRO). Referring to the early years of CSIRO, Sir Frederick writes of that period as one in which money was easy to obtain. It was a period, spanning the 1950 s and most of the $1960 \mathrm{~s}$, of comparative prosperity and stability for Australia, a period which saw the setting up of the Murray Committee on Australian Universities and the implementation of that Committee's recommendations. These met the pressing need for additional support for existing universities and led to the establishment of now universities and to a considerable expansion in university research. These important steps, which had the full support of the Executive of CSIRO - the Chairman, Sir Ian CluniesRoss, was a member of the Murray Committee-led to a much improved balance in the national research effort between university and government laboratories and, incidentally, reduced a measure of undesirable friction which existed between some university scientific staff and CSIRO.

There was, and still is, however, a serious imbalance as far as industrial research is concerned, a situation which was bettered to a limited extent in that same period by the introduction of industrial research and development grants by the government, a step which was also actively supported by CSIRO. At present, then, the inadequate level of research activity in manufacturing industry is in marked contrast to the substantial proportion of the country's total research effort represented by government research agencies of which the largest is CSIRO.

By the late 1960s CSIRO had grown substantially, setting up new divisions and expanding and changing the direction of existing divisions, and in spite of very limited growth during the 1970 s the total staff now exceeds 7,000, one-third of whom are professional scientists. As we moved into the 1970s, however, it became increasingly evident that CSIRO

\begin{tabular}{|c|c|c|}
\hline \multicolumn{3}{|c|}{ Contents } \\
\hline Looking to the future & J. R. Price & 631 \\
\hline A personal account of the & & \\
\hline $\begin{array}{l}\text { historic development of } \\
\text { CSIRO }\end{array}$ & F.W. G. White & 633 \\
\hline Wildlife research & H. J. Frith & 637 \\
\hline Animal nutrition to human & & \\
\hline $\begin{array}{l}\text { nutrition: achievements and } \\
\text { prospects }\end{array}$ & B.S. Hetzel & 640 \\
\hline $\begin{array}{l}\text { Growth of CSIRO's interests } \\
\text { in food research }\end{array}$ & $\begin{array}{l}J . M . \text { Bastian and } \\
\text { J. R. Vickery }\end{array}$ & 644 \\
\hline Minerals research & I. E. Newnham & 647 \\
\hline Wool structure and biosynthesis & $\begin{array}{l}\text { R. D. B. Fraser and } \\
\text { J. M. Gillespie }\end{array}$ & 650 \\
\hline Fifty years of plant research & L. T. Evans & 655 \\
\hline $\begin{array}{l}\text { Synthetic polymer research } \\
\text { in CSIRO }\end{array}$ & D. H. Solomon & 658 \\
\hline $\begin{array}{l}\text { Australian journals of scientific } \\
\text { research }\end{array}$ & B. J. Walby & 661 \\
\hline $\begin{array}{l}\text { Nature is part } \\
\text { Australian Sci }\end{array}$ & $\begin{array}{l}\text { Dr F. G. Lennox of } \\
\text { e, London for advice }\end{array}$ & \\
\hline
\end{tabular}

